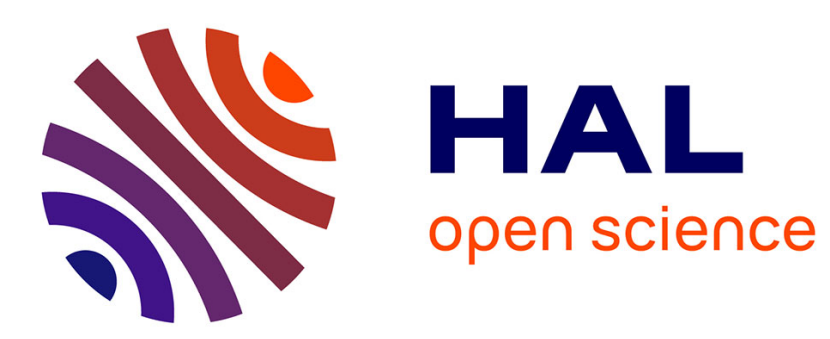

\title{
City festivals : creativity and control in staged urban experiences
}

Marjana Johansson, Jerzy Kociatkiewicz

\section{To cite this version:}

Marjana Johansson, Jerzy Kociatkiewicz. City festivals : creativity and control in staged urban experiences. European Urban and Regional Studies, 2011, 18 (4), pp.392 - 405. 10.1177/0969776411407810 . hal-02423783

\section{HAL Id: hal-02423783 \\ https://hal.science/hal-02423783}

Submitted on 25 Dec 2019

HAL is a multi-disciplinary open access archive for the deposit and dissemination of scientific research documents, whether they are published or not. The documents may come from teaching and research institutions in France or abroad, or from public or private research centers.
L'archive ouverte pluridisciplinaire HAL, est destinée au dépôt et à la diffusion de documents scientifiques de niveau recherche, publiés ou non, émanant des établissements d'enseignement et de recherche français ou étrangers, des laboratoires publics ou privés. 


\title{
City Festivals: Creativity and control in staged urban experiences
}

\author{
Marjana Johansson \\ Essex Business School, University of Essex \\ mjohana@essex.ac.uk \\ and \\ Jerzy Kociatkiewicz \\ Essex Business School, University of Essex \\ kociak@kociak.org
}

\begin{abstract}
On a global market, cities aim to develop a distinct profile to attract mobile consumers. One increasingly used means to attain distinction is to brand the city as experience space. Particularly, the urban festival has become a popular organizational form for creating experience spaces, and for marketing cities. Festivals are often strategically conceived with the purpose of promoting a 'distinctive city', in line with uniqueness being the keystone of success in the experience economy. This paper applies an experience economy framework to analyse city festivals as potentially transformative practices, helping reimagine urban space and reshape urban identity. Building on empirical studies of Stockholm Culture Festival and the Nowy Kercelak Fair in Warsaw, it examines the tension between controlled image production and carnivalesque celebration and the extent to which the meanings and flow of urban space can be managed. Using Lefebvre's notion of the production of space and Deleuze and Guattari's concepts of de- and reterritorialization, this paper critically assesses the possibility of reshaping urban practices through the staging of festivals, and the potential for creativity and expression extant in managed staging of experience.
\end{abstract}

Keywords: Experience economy, city marketing, festival, urban space

\section{Introduction}

Building on Toffler's (1970) vision of the increasing role of the immaterial for economic development, the experience economy emerged as a concept in the 1990s to denote a socio-economic system where aesthetic experiences, rather than goods or services, form the basis for generating value. First theorized from a sociological perspective by Schulze (1992), and later brought to popular attention by Pine and Gilmore's business-oriented approach (1999), the proposed framework has since formed a basis for exploring how experiences are produced and consumed in a variety of contemporary settings (e.g. Hjorth and Kostera, 2007; Sundbo and Darmer, 2008). Often, the aim is to analyze how exciting experiences can be produced to attract consumers. In relation to place promotion, the experience economy framework has for example been applied to explore how particular places are packaged (Hayes and Macleod, 2007; Avdikos 2011), how visitors' experiences can be measured (Oh et al., 2007), and as a basis for developing marketing destination strategies (Morgan et. al., 2009). The branding of physical sites as experience spaces is part of the logic of experience-based value creation. Cities are no exception, and the attempt to recast cities as 
experience spaces is often reflected in the marketing of the cultural and social activities that the city has to offer. In the experience economy the city becomes 'a site of use, symbolism and experience' (Marling et al., 2009: 870). This has implications for urban strategic planning procedures, and for how the city space is mobilized for various activities.

A popular organizational form for creating experience spaces, and for marketing cities, is the urban festival. Festivals and other cultural events are seen as a means to contribute to a positive image of a place, and to create employment opportunities, to further economic growth (Herrero et al., 2007), and entrepreneurial confidence (Richards, 2007). They are a vehicle for bringing together a range of stakeholders, such as performers, visitors, inhabitants, volunteers, entrepreneurs, and the public sector, and have thus become 'increasingly written into civic cultural policies as both product and framework, designed to attract a wealthy target market and furnish the city with a competitive image' (Jamieson, 2004: 66). To organize such events is often part of an official strategy for enhancing the attractiveness of a place (Yeoman et al., 2004; Smith,. and von Krogh Strand 2011). As a result of a general culturalization of the economy (du Gay and Pryke, 2002; Löfgren and Willim, 2005), festivals and events have become marked features of contemporary marketing and development strategies. Festivals may be strategically conceived with the purpose of promoting a 'distinctive city' (Markusen and Schrock, 2006), distinctiveness being an important feature of the experience economy. On the other hand, such an employment of the festival has also lead to considerations of a commoditization and spectacularization of cultural events, where the traditionally perceived benefits for the local community can be questioned (Waterman, 1998; Richards, 2007).

In this paper, we use the experience economy framework to explore the ways in which urban space is staged, acted upon, and transformed in order to provide an intended experience. Key to the experience economy is to manage experiences to produce a desired effect; however, the contradictory space that is the city does not easily lend itself to unambiguous presentation. The tension between the managed and the subversive becomes an essential factor which shapes urban experience-based projects. To illustrate the issue empirically, we will present three vignettes of reorganizing urban space through the means of events. Their composition is designed to explore rationales and practices of urban festival organizing, to address the aforementioned tension, and to foreground the experience of festival participation. The examples are set in Sweden and Poland, two countries located at different edges of the European social, economic, and political core, and both known well enough by us to consider them home contexts.

In what follows, we will first position the city in the experience economy by outlining the features of such an economy and what is deemed necessary in order to successfully compete in it. We will then pay particular attention to what this means in terms of urban space; how space is conceived of being something which can be staged and consumed, and what this means in terms of initiating and carrying out activities. Our particular focus will be on the urban festival as a transformative intervention. After an outline of the background and growth of the modern urban festival, we proceed to present our empirical examples. Finally, we offer some concluding remarks which draw upon the foregoing analysis of spatial practices of festivalization to address our main concern, the inherent tension between control and carnival, and the extent to which the meanings and flow of urban space can be managed.

\section{The Experience Economy and the City}

The experience economy is about differentiation and engagement. According to its logic, what is offered needs to be distinctive so as to attract consumers, and it needs to provide an experience dimension which has the potential to engage the consumer beyond merely purchasing a product or service. How that experience is constructed, interpreted and lived is however a complex phenomenon which presents several challenges (Sundbo and Darmer, 2008). Production processes need to be designed and carried out to create a symbolic value universe of meaning which imbues the core product. For the city in the experience economy, this means communicating an 'attractive atmosphere, which comes from place-bound activities, events and services, attractive places and diverse social spaces, which make visitors and residents feel inspired, involved and connected to the place' (Lorentzen, 2009: 840). The notion of constructing an idea of place - that is, of a distinctive identity - is pivotal. When offerings are ample and the consumer has the power of choice, 
sticking out of the crowd is imperative. An increased affluence of a larger number of consumers coupled with an increased mobility result in cities being pitted against each other on a global market. According to Zukin (1995), cities compete on the basis of a symbolic economy, on how their attractiveness can be packaged and communicated. This ties in with Markusen and Schrock's (2006) concept of 'the distinctive city', according to which cities competing for attention on the global market place seek distinction in productive structure, consumption and identity. How global ideas of the experience economy are translated into local, urban, and time-constrained practices therefore provides a fruitful approach to contribute to our understanding of the contemporary interplay between what Tuan (1977) terms space-the abstract and totalizing experience of being - and place - the rooted site of embodied belonging. However, the experience economy as envisaged by Pine and Gilmore (1999) also enables producing a high degree of differentiation and mass customization simultaneously, that is, uniqueness is mass-produced. The question of what is 'real' in terms of being genuine instead becomes a question of what is construed as real and genuine. In the context of urban destination marketing, the contemporary visitor is looking to experience the authentic city (Russo and Sans, 2009). A 'soul' of the city is therefore often framed and presented in a soundbite manner in promotion campaigns to communicate genuineness. An urban festival often serves to show the city in a new light by uncovering hitherto neglected or hidden features, and by momentarily disrupting the normal city flow (of traffic, for example). Such a seemingly spontaneous event is nevertheless tightly managed. Not any, random 'undiscovered features' of the city emerge, but rather those that the festival organizers wish to emphasize. The city does not only serve as a backdrop for the festival; the festival also transforms the city both by altering its spatial constitution and by attributing the city with a particular identity. To do so, the city has to be reordered and reinvented. In the name of the festival unwanted elements, including people are removed, streets are closed off, buildings are refurbished (or perhaps torn down), alternative spaces are opened up and extra-ordinary performances are staged in places usually reserved for more mundane activities. The festival demands a re-presentation of space in order to enable the locking of the festival gaze onto the city to engross the visitors.
Constructing the festivalized city thus means interrupting, redirecting, and altering existing flows as well as creating new ones. The festivalized city presents a different rhythm, to follow Lefebvre (1992 and 2004). Rhythm is for Lefebvre a concept for understanding time and space, and seeing the urban 'not as a singular abstract temporality but as the site where multiple temporalities collide' (Crang, 2001: 189). The city is lived in temporal rhythms of activities and people. Rather than viewing the city as a unitary phenomenon we may look at urban practices that uphold the city (de Certeau, 1984). Spatialization - the making of space happens through practice, through the appropriation of urban places for temporary use (Crang, 2001: 190). Both Lefebvre and de Certeau are concerned with the everyday life, whereas the festivalized city can be seen as existing outside, or perhaps parallel to, the everyday. In any case the city is not a stable entity but rather 'a becoming, through circulation, combination and recombination of people and things' (Crang, 2001: 190).

In the context of the festival, this becomes a means for reconfiguring the city space for alternative activities, outside the everyday realm. The city becomes an experiencescape, a 'stylized [landscape] that [is] strategically planned, laid out and designed' (O'Dell, 2005: 16). Ordinary space is transformed into festival space, a 'framed spontaneous play which contrasts routine everyday life' (Jamieson, 2004: 65). The seemingly carnivalesque character of the festival is, however, tightly directed:

behind the animated street scenes, the gaze is influenced by stakeholder, institutions of local government, and an expanding service economy, which benefit from the promotion of the festival's playfulness and liminality. ... Although spaces appear as though spontaneously formed by the company of strangers and the collective experience of performances, the city en fête is also the result of painstaking planning by a city administration that seeks to control the ways in which public spaces change. The city is nonetheless redefined by the altered energy and velocity of strategically planned festivalized spaces (Jamieson, 2004: 65).

As well as being a meticulously choreographed event, the festival provides a space for redefining the city. However, a festival also has the potential to swell beyond its intended boundaries. It appears as a close relative of a carnival, as described and analyzed by Bakhtin (1984): a momentary disruption of the status quo, 
exuberant, outrageous, and sometimes even violent, yet also integrated into the larger, hierarchical social order. Excitement, danger, and uncertainty, although inimical to managerial control, are crucial ingredients of festival and city experiences, and their framing in the experience economy (Kociatkiewicz and Kostera, 2010). Due to its spectacular and participatory character, the festival presents an appealing marketing device for policy-makers to use to enhance the city's image. Before exploring the background and growth of the urban festival, we will first discuss its setting: urban space.

\section{The production of urban space}

Lefebvre declared that '(social) space is a (social) product' (1974/91: 26). The assertion is interesting in that it goes beyond the claim that space, much like the rest of reality, is socially created and interpreted through social interaction. It is important to note here that the word 'social' is superfluous in Lefebvre's quote. Anthropologists such as Lévi-Strauss (1962/6) and linguists like Kristeva (1982) have demonstrated that human experience is inherently social, mediated by culture and language, and any non-social events are bound to remain unknown and unknowable, reachable, if at all, only as mystical insights. Lefebvre speaks not just of the construction, but of the production of space, seeing it as subject to economic processes governing human existence. Space in general, and urban space in particular cannot be thought of in isolation from the economic structuring of human experience. It is constituted through, and remains a site of, continued economic activity structuring every aspect of urban life. Consequently, the rise of experience economy as the dominant mode of economic interaction, as proclaimed by Pine and Gilmore (1999), is bound to reimagine urban space as a site of staged and witnessed experiences. In this study we examine city festivals as harbingers of this transformation, changing cityscape on a significant, if temporary scale, and use them as a lens for examining the organizational underpinnings of the production and consumption of urban space.

While sites of festival activity range from metropolises to village greens to desert wastes, our focus in this text lies specifically with urban festivals. In this matter we encounter much in the way of historical precedents: already Huizinga's (1924/2001) study of the high middle ages describes the medieval city as a colourful site of spectacle and celebration, lived and experienced through processions, public executions, and showmanly sermons of itinerant preachers. The very word festival conjures up images of 'jostling crowds, overspilling bars, and cacophonies of multilingual conversations; (Jamieson, 2004: 64), a rupture in the everyday and a feast for the senses. City space, always rife with accrued significance, imbues the festival with meaning, but the process is reciprocal, as the festival provides new meanings for the city it inhabits. The festival serves to displace artefacts of the city from their functional use to a symbolic realm, thereby ascribing them with new meanings (Haapala, 2005). In the course of this transformation, the streets, buildings, and parks of the city are temporarily claimed to assist in the production of the festive city space. The city's architecture is mobilized for experience-based consumption, as 'designing for experience requires connecting architecture to the user's personal dreams and desires' (Klingmann, 2007: 19). To construct such an enchanted zone is a major organizational endeavour entailing construction projects, permits and policing. The festival can, temporarily, become a hub for organizing the urban space, serving as a focal point for reorganization of the flow, pace, and navigability of the city space, as well as providing a means of legitimization for any reconfiguration of the city undertaken at the time (Kociatkiewicz and Kostera, 2001).

In light of the above, we argue that the festival transforms city space and city life through two significant, if related processes. First, we see it in relation to the concept of territorialization. Specifically, we refer to Deleuze and Guattari's (1986) understanding of territorialization to frame how, by disturbing the spatial routines of everyday life, a festival deterritorializes city space, casting out or subverting the dominant meanings and institutions. Inviting new social actors into the festival space, bringing in new themes and activities, changing established pathways and behaviours, decontextualizes the familiar signs and references, opening up the possibility of questioning the taken-for-granted interpretations embedded in everyday spatial practices. In Deleuzian terms, festival events change striated space of the familiar environment into the nomadic smooth space of the unexpected. The festival also allows for the subsequent reterritorialization of urban space in new configurations, using event experiences as blueprints for subsequent sedimentation of spatial 
practices: reforming the striated space enriched by premade themes brought in by the organizers as well as the new interpretations created by the participants in the course of the festival.

Second, we view transformations of urban space in the experience economy context to explore what this means for defining which activities are deemed desirable and valuable, and how they should be carried out in practice. Seen from this perspective, the Lefebvrian production of space is, we argue, to an extent informed by the dicta of the experience economy. Specifically, we want to point to the sanitizing aspects of the city being cast as vibrant and multivocal along the lines of differentiation in the experience economy, but at the same time being directed and staged in particular ways, which allow for the city to be compared to other cities along the lines of mass customization. In order for a city to be a place to be reckoned with in the contemporary economy it has to harbour certain activities (as we will see in the Stockholm Culture Festival example), and those activities have to be carried out according to certain criteria, which are deemed acceptable (as exemplified by Nowy Kercelak). The result is carefully crafted urban space aimed at producing authentic experiences. Next, we will outline how the urban festival has been mobilized to assist in the process.

\section{The urban festival}

The emergence of the modern urban festival can be traced back to the 19th century with the Bayreuth Festival in 1876 and, some decades later, the Salzburger Festspiele in 1920 (Quinn, 2005). The cultural festivals of the 19th century were concerned with displaying what was regarded as high art, reflecting the position and acquired taste of the urban bourgeoisie. In post-war Europe one element in the striving for unity and stability was the establishment of several urban festivals, among them the Edinburgh International Festival and the Avignon festival, both founded in 1947. Post-war festivals generally still displayed a penchant for high art and a civilizing aim, while the Avignon festival can be seen as an early attempt to promote inclusiveness, accessibility and new forms of interaction between audience, artists and place' (Quinn, 2005: 929-930), much in the same vein as the simultaneously burgeoning Edinburgh Fringe Festival. The questioning and subverting of dominant art paradigms reflected the socio-cultural climate of the 60 s and 70s, and social movement agendas including feminism, environmentalism and gay rights saw the appropriation of urban space for demonstrations and other carnivalesque forms of intervention. While the aim of these events was to question and transgress boundaries of prevalent social and political order, the urban festival was harnessed for more market-oriented purposes in the following decades. The increased trend of regeneration of dilapidated industrial urban areas coupled with a growth of the leisure and tourism industry has seen cities being increasingly marketed as objects of consumption, with festivals constituting a central part of the image creation:

In the context of urban development, from the early 1980's there has been a process that can be characterized as 'festivalisation', which has been linked to the economic restructuring of cities, inter-city competitiveness, and the drive to develop cities as large-scale platforms for the creation and consumption of 'cultural experience' (AEA, 2006).

The European Capital of Culture project was initiated in 1985 as an official initiative to foster a pan-European culture by displaying the richness of the European urban cultural heritage. The flagship example of urban regeneration attributed to the Capital of Culture project is Glasgow, the 1990 Capital of Culture. The celebrations were seen as a success in terms of attributing the city with a cultural image and leaving the post-war industrial profile behind. Subsequent Capitals of Culture, for example Stockholm in 1998, have used Glasgow as a benchmark to demonstrate how an emphasis on culture can provide economic benefits. Culture becomes a device with the help of which cities are conceived of as brands that attract visitors in search of experiences (Anholt, 2008; Hudson and Ritchie, 2009). A primary example of a city which has chosen festivals as the preferred cultural form for its brand marketing is Edinburgh. The Festivals Edinburgh network consists of 12 festivals with an annual combined number of visitors amounting to 4 million (European Festivals Association, 2009), giving rise to the label 'The World's Festival City'. From having been a means for displaying the cultural wealth of a city, the urban festival has increasingly become a device that can bring economic as well as social and cultural benefits.

In what follows, we present three vignettes: two dealing with urban festivalization, and one serving as a 
post-festival reflection. The first example examines the Stockholm Culture Festival, providing an overview of festival advocacy and organization, and the following two vignettes, presenting the Nowy Kercelak fair in Warsaw and the aftermath of New Year celebrations in Wrocław, concentrate on participant experiences throughout and after a festival event. In all three examples we use the experience economy framework to build on previous research into 'the transformative aspects that can be identified in relation to experienceoriented urban development' (Lorentzen and Jahn Hansen, 2009: 817) whilst specifically exploring the spatial and symbolic transformations produced by the urban festival.

The main examples are set in two European capitals: Stockholm and Warsaw. The two locales have been chosen to show commonalities in urban practices of festivalization as well as to highlight some contrasting features. First, they represent two rather different cityscapes. The former has enjoyed a sustained peaceful existence with its historical heritage conserved. Stockholm Culture Festival is set in an economy wellacquainted with the discourse of experience-based value generation and urban development, presented as benefitting from the layers of history and culture present and accessible within the city space.

Warsaw, by contrast, was ravaged by destruction during the war and subsequently rebuilt under communist rule (as was, to a lesser extent, Wrocław). Urban regeneration has formed a central part of the economic and cultural transition of postsocialist economies (Murzyn, 2006), part of which has involved forging new urban identities through 'the recasting of postsocialist spaces' (Young and Kaczmarek, 2008: 53). The recent entry into the common European economic and cultural discourse has further bearings on how urban space is constructed in terms of which activities are deemed appropriate, and how they are staged. This recasting is partly attempted through the means of experience-based consumption, the focal interest of this paper. The Polish sites are thus marked by a long-standing historical discourse of continued deterritorialization, and of reinscription of meanings onto the changing urban space. The two settings thus provide interesting juxtapositions in terms of the spaces subject to deterritorialization by the festivals as well as in the reterritorializing effects the festivals attempt to bring about: the new meanings inscribed onto the cities, the (dis)order envisaged by the organizers and experienced by festival participants.

Our discussion of the examples is based on participant observation, media coverage, and other documentation. The participant observations in Sweden were carried out at the time of the inception of the festival, and have subsequently been followed up with publicly available documentation. The Stockholm Culture Festival presents an illuminating example of how the start of a large-scale festival is grounded in a market-based discourse regarding the imperative to compete for prestige, and of how such ideas are translated into practice. The emphasis of the first case is thus on the explicit intentions with the festival and its subsequent design and growth. The studies carried out in Poland, by contrast, focused on festivals viewed from a participant's perspective. Here, participant observation centred on the subjective experience of taking part in the activities, documented through field notes and photographs of the event. Afterwards, press reports were used to contextualize these experiences. Results from the Polish part of the study served also as a basis of a Jungian analysis of the dark side of experience economy, as reported in Kociatkiewicz and Kostera (2010).

In what follows, we will discuss the examples in the context of our chosen theoretical framework. Specifically, we aim to examine the conflicting visions of the festival as an intentional vehicle of city redevelopment, as a carnivalesque arena for subverting everyday notions of place, and as a space for negotiating the meaning of urban practices.

\section{City staging: the Stockholm Culture Festival}

In 2006 the city of Stockholm saw the birth of the Stockholm Culture Festival. Funded by the city council, the festival was conceived to flaunt the cultural heritage and richness of the city, and to enhance its profile as a culturally vibrant capital. An explicit longterm aim has been to increase the number of visitors to the capital and to enhance its cultural image, in line with the discourses surrounding the festivalization of cities as previously outlined. The aim of the festival is to make the city come alive, to create a space for inhabitants and visitors to enjoy and experience the city through the cultural activities on offer. The festival 
includes a vast array of performances staged around the city during six days, easily accessible, and mostly free to the public. The festival has shown a steady progression; the number of visitors has grown from 250,000 in the first year to over 300,000 , and the number of events has increased from 400 to over 500 . At its inception in 2006 the festival was the contested object of a political debate, with reports stating that if the conservatives were to seize the power in Stockholm in the 2007 elections, the new festival would be disposed of, as there were more pressing issues to spend taxpayers' money on (Brandel, 2006). However, the first festival was a success in terms of visitor numbers and positive press, and although a shift in the municipal power constellations did occur as a result of the elections, the festival was granted a mandate to continue. It was seen to merit its place as a way of contributing to a positive image of Stockholm on an international scale. By attracting large audiences and by staging performances according to prevailing ideas of cultural value, the festival claimed its place in an experience-based economic framework. It also performed the important role of addressing a perceived significant lack: unlike 'many other European cities' Stockholm did not at that time have a high-profile cultural festival (Nilsson, 2005). The perception of there being a lack is not only indicative of the role festivals play in contributing to a positive city image, but also of the previously mentioned importance of creating a distinctive city in the global experience economy. Festivals are important in this respect, as they represent the kind of urban entrepreneurial displays (Quinn, 2005) that are organized to attract investments for restructuring and regeneration, and to create a favourable image of the city.

The motto for the festival, 'high quality and a low threshold', signifies the aim to make culture accessible for all while still maintaining a high quality. Contents include children's activities, film, visual art, performance art, walks and photography. The guiding principle is to provide a broad range of acts which cater to a wide audience, while also providing space for more avant-garde acts. An explicit aim is also to provide the opportunity to participate for those who do not normally consume cultural activities. The participatory aspect can be seen as a representation of the contemporary notion of mobilizing culture for social inclusion - but the participation should in this case be limited to culturally 'tasteful' activities. When outlining how the new festival would fulfil this aim, a particular example has been invoked as a negative benchmark. The example consistently mentioned is the Stockholm Water Festival, which was organized between 1991 and 1999, and which from a successful beginning mutated into something which was considered undesirable and subsequently terminated. The Culture Festival was founded in the vacuum that was left by the Water Festival with the explicit aim not to replicate the mistake, so when decisions are made about the Culture Festival it seems the Water Festival serves as a negative identification. The latter became too commercial and rowdy, while the new and improved Stockholm Culture Festival was to be more cultural, 'a national and international festival of a high standard, with no beer tents' (Boldemann, 2005). Food, drink and trinket sales were explicitly banned from the agenda at the outset, to avoid the overt commercialization and subsequent devaluation of the festival. The last years, however, have seen a change to the non-commercial profile, with catering services and a market being introduced in 2008. To maintain a high quality profile only small-scale design and handicraft items are allowed, and the market is framed as 'an additional way to display different forms of culture' (Ingelman-Sundberg, 2009). The spectre of the Water Festival was invoked anew in the press at the introduction of such commercial elements, but any suggested morphing between the two was steadfastly rebuked by the festival director (Laquist, 2009). Although the Culture Festival might be displaying similar traits as the Water Festival, it is not comparable with the latter. Instead, the proclaimed identification is with the Edinburgh International Festival, which is seen to carry a high profile reputation. However, set in the context of the experience economy and the global competition among cities, the Stockholm Culture Festival itself may be seen as a sign of the commoditization of experiences in line with some of the reasons put forward for its founding (image, visitors, an international profile). The delicate navigation between the Scylla of elitism and the Charybdis of commerce that the organizers perform is an indication of the perceived tension between genuine cultural activities and commoditized carnival. In the experience economy, however, with its massproduction of authenticity and uniqueness, such boundaries become blurred.

The aforementioned notions of presenting particular 
cultural activities and of showcasing the city's architectural heritage also serve as parameters for reordering the city space. The deterritorialization of the everyday urban space is a carefully orchestrated attempt at providing an alternative, yet socially and culturally acceptable reading of the city. Spatially, the Culture Festival is organized around a number of public squares, which constitute the main stages of the festival. A new map is effectively drawn up by the festival, where the designated main locations constitute the nodes of an experience-based topography. The previously mentioned focus on accessibility and wish to get rid of the elite label attached to some art forms is exemplified by the Royal Opera's outdoor taster performances. By bringing high culture out on the streets it is said to become more accessible, and lose its negative connotations of exclusion. The Royal Opera, rich in symbolism that for many alludes to elitism, is reframed through the open access performances. The festival is said to 'provide space for new meetings, erase boundaries, subvert hierarchies, and question ideas of acceptable behaviour ... the important thing being that we are free to reformulate [meanings]' (Nyström, 2007). Here, the link to a Bakhtinian carnival becomes apparent. However, like the carnival is a momentary, prescribed subversion the seemingly unpredictable experiencescape can be seen to be organized along predetermined lines of what constitutes economic and social benefits.

While the aim is to achieve an international position for the festival, it was also strongly linked to the inhabitants of Stockholm from the start, to 'provide knowledge of the rich cultural life the city has to offer, and to inspire people to seek out culture' (Carp, 2005). It is important that the inhabitants of Stockholm like their festival. It is to provide the reconfiguration of activities and people, and it is to inspire people to challenge the traditional cityscape and architecture. One important aim, then, is to help the inhabitants claim what is rightfully theirs by opening up the space to alternative activities, by removing barriers that are normally in place so that different flows can be created. One flow that the festival aims to establish is that of people between boroughs, to get them acquainted with those parts of the city that they do not normally visit. This is an explicit attempt at creating movement that transcends entrenched social and geographical city boundaries, and a way of trying to overcome the inherent risk that experience-based urban spatial development may in fact produce division between social groups, and exclusion of some social groups (Lorentzen and Jahn Hansen, 2009). Akin to the danger of cultural events turning in to non-participatory spectacles in the name of image enhancement (Richards, 2007), the drawing up of an alternative cityscape may create new social faultlines or confirm existing ones, through for example the alienation of local residents. Generating new flows and showing alternative ways of using the urban space opens up possibilities for different narratives and fresh interpretations, but those interpretations are not necessarily easily managed.

The Culture Festival also needs a distinct profile, as 'people are tired of city festivals that are all alike; this [festival] is different' (Andersson, 2006). The festival has to have a unique signature, 'it has to mirror our contemporary, multicultural metropolis' (Boldemann, 2005). The idea of uniqueness is important, as a risk of organizing urban events are their potential formulaic character, and of being 'devoid of any real connections with place' (Quinn, 2005: 928). Hence, uniqueness is crucial in order to establish a 'real connection' with a place. However, it can be argued that this 'real' connection can be crafted by providing a plausible narrative. A legitimate position is created through linking the temporary festival to the place where it is held; for example by pointing to the history or the natural landscape, or, as in the case of the Stockholm Culture Festival, by adhering to the received wisdom that a city without a festival is lacking something important. Further, the Culture Festival is narratively legitimized by being positioned in opposition to the Water Festival, which developed into something unsavoury. Second, for a festival to be unique it presumably has to possess an authentic character - but that character is paradoxically attained by adhering to global models for what a modern, urban festival should offer. Otherwise the festival cannot be positioned in relation to other urban festivals, which is imperative for being able to compete with other experience-focused cities. The mirroring of the contemporary metropolis results in sanitized, mass-produced uniqueness. Next, we will take a closer look at another sanitizing narrative device for creating authenticity, namely nostalgia. 


\section{Sanitizing festival space: Nowy Kercelak in Warsaw}

Nowy Kercelak (New Kercelak) was an annual nostalgia fair and festival, organized in Warsaw from 2007 to 2009. The studied event took place in June 2008. The name Kercelak denotes a celebrated marketplace of central Warsaw that operated in force from 1867 until World War II, and clung on to existence in a limited fashion until 1947. It was well known as a commercial venue for trading every sort of good imaginable, but also as a site of street entertainment, illicit deals, organized and unorganized crime. An official magazine published by the local government quotes the following reminiscence:

Here you can get everything from tripe with meatballs to a slightly used Ford, not to mention such specialties as: purebred pigeons, male clothing, phonographs, watches without machinery, guns, goldfish feed.... You could even order a Bengali tiger there, they would steal it from the zoo and deliver (Wiechecki, 1966, quoted in Kołodziejska, 2008: 1).

It is interesting to note not only the romanticized representation of illegal activities of the past, but also the implicit parallels to Stadion (officially called Jarmark Europa, or Europe Fair), another important Warsaw marketplace, which was closed only a few months before the studied festival. Up until recently it was one of the largest open-air marketplaces in Europe, harbouring a similar reputation of inexhaustible variety of products (legal or otherwise) on offer as well as of serving as a hotbed of petty criminal activity. Successive local governments of Warsaw announced their intention to close Stadion, described as unbefitting a major European capital, but only the approaching organization of Euro 2012 football championships provided an appropriate impetus to actualize the closure.

The Nowy Kercelak festival deliberately invoked memories of both marketplaces - Kercelak and Stadion - to construct its meaning and significance. The actual festival, though, was clearly more of an entertainment than a commercial event. A large stage forming the centrepiece of the festival hosted a number of musical acts and contests, other attractions such as period-dressed acrobats served as smaller attractions while various market stalls lining the festival area framed the event space. The cobbled streets chosen as the site for the festival tied it to an imaginary pre-war Warsaw while long-unused rails still embedded among the cobblestones allowed for a horse-driven tram to operate. The foregrounding of the scant remnants of old Warsaw served to accentuate the boundary between festival space and everyday life--simultaneously deterritorializing the space of the festival streets through its symbolic removal from contemporary context and reinscribing it with layers of history ignored in the usual experience of presentday Warsaw.

A particularly notable performer, dressed up in antiquated clothes in the image of a Warsaw delinquent from 1930s, invited passersby for a game of dice or three card monte. These games are well known as confidence tricks practiced in marketplaces, obviously rigged, and thus the invitation was clearly for the participant to agree to get cheated rather than to gamble. The uncertainty of winning is replaced with a certainty of losing - the original risky but also exciting elements of the game are excised for the sake of the sanitised festival space. All kinds of experiences can be represented as pleasurable when recontextualized in a festival setting, infused with a nostalgic mood, and served as part of the experience economy offering.

The figure of the pretend-hustler acknowledges the legacy of crime of the Kercelak market, but also witnesses the remarkable power of the experience economy approach: even the most unpleasant event (that of being swindled) can be recast as an enticing experience. In the entertainment version, visitors expect to be cheated, effectively removing the element of danger from the experience. Further carnivalesque inversions abound in this reinterpretation: Warsaw dwellers, burdened with a country-wide reputation of crooks and cheats are re-presented as victims and invited to live out the (possibly novel) experience of victimhood. Commercial endeavour dominating the market is recast as a cultural legacy, celebrated for its folklore rather than for its contribution to the local economy. Thus, the festival does, as KarpińskaKrakowiak (2009) notes, perpetuate urban image and reputation, but only through allowing for retranslation and reinterpretation of that image.

Nowy Kercelak aims to create a fabled space alluding to Warsaw history and legend, staging it in a contemporary entertainment setting of a street fair. It can be seen as an example of a 'nostalgiascape' (Gyimóthy, 2005), a representation of events and 
identities of a historic character. Creation of this space involves not only retrieval of memory (and history), but also its translation into a form suitable for a different audience, and thus its reinscription onto a contemporary landscape, all the while accounting for the aims of the fair's organizers. One of the most distinct features of this process is the attempted domestication of the market space, fabled, after all, as much for legitimate trade as for the amount of illegal business and swindling to be found on its premises. But translation, of texts as well as of ideas, events, or organizations always introduces new ideas, changes available interpretations, and adds new possible meanings (Steiner, 1975; Czarniawska, 1994). A fair is offered up as a replacement for a marketplace, much as the Culture Festival was positioned as a preferred alternative to the Water Festival in Stockholm. Both festivals allude to previous, unsightly versions, to establish their own rightful position as pleasurable, entertaining and enriching experiences without the unpleasant side-effects.

\section{Aftermath}

Our final vignette concerns not a celebratory event as it happens, but rather its immediate consequences: the post-festival transformation of space in Wrocław, a city in Western Poland. New Years Eve of 2008 saw the country's largest celebrations take place in the City Square, drawing tens of thousands of mostly intoxicated inhabitants and visitors to a music show and fireworks display. The festival was noisy, raucous, and subsequently proclaimed a major success by most of the newspapers. The morning after the celebrations, however, shows little evidence of the wild carnival of the night before. There is a flurry of activities in the city centre: large, immaculately choreographed groups of cleaners work hard to remove all traces of the previous night's revelry. By noon they manage to finish most of their work. Though the festival spilled out onto the whole city space, the cleaning action is strictly limited in its spatial extent to a few streets surrounding the City Square. The rest of the city feels empty and deserted. Municipal services, including public transport, are effectively on hold, despite posted schedules promising otherwise. Shops, cafes, and restaurants are closed. Even the weather, uncharacteristically warm on the night before, has changed and biting cold underscores the stillness of the abandoned streets. Only a few forlorn-looking tourists stumble around the empty areas while small groups of frozen would-be passengers huddle on bus and tram stops, trying feebly to ward off cold while they wait for delayed and cancelled buses. The city looks and feels abandoned, or perhaps even dead: the result not of a cataclysm, but of a carefully planned and joyous celebration.

The experience event of the festival has run its course, with the drabness of the everyday reasserting its hold on the urban space as organized contingents of street cleaners work hard to remove all traces of celebration in the city centre. Their task is clearly deemed to be of utmost importance, prioritized well over the preservation of the ongoing urban practice, as evidenced by the breakdown of public transport and the closing of shops, kiosks, cafes, and restaurants. This is truly the descent into the desert of the real (Baudrillard, 1985/94), forceful reterritorialization of urban space, purged of the traces of the festival, but also of the central components of city life: continuous flows of activity, ongoing and uninterrupted social processes, and the overabundance of meaning (cf. Castells, 1996; Urry, 2000). In stark contrast to the festival event, no audience is expected to participate, and spatial practices of the city organization are no longer open to outside interpretations. Indeed, the festival is now redefined as a demarcated event, not an expression of urban life but its carnivalesque inversion.

\section{Concluding remarks}

When placing the city in the experience economy, it becomes subsumed into a discourse of global competition where the crucial feat of distinctiveness, with its subsequent economic benefits, is achieved by means of presenting the city as a gigantic experiencebased playground. Its architectural structures and socio-cultural features are mobilized, framed and represented accordingly to imbue the city with new meanings. To achieve this, a physical transformation of the urban space is undertaken in order to bring about a symbolic transformation of the city's image and attraction power. However, in order to portray the city as vibrant and teeming with a variety of activities, it is simultaneously presented as a simplified package, which is expected to evoke a preferred range of connotations. A city is always rich in experiences, but only particular kinds can serve the purpose of 
the experience economy. It therefore becomes crucial to maintain control over the experience production process. The festival, perceived as an easily marketable, aesthetic experience which is contained in time and space, presents an attractive means for such production. The vignettes which we have presented showed three different aspects of festivalization of the city: a concerted, if not unambiguously successful, attempt at building a tourist-friendly, yet vibrant image in case of Stockholm Culture Festival; an invocation of a sanitized translation of the city's past in Nowy Kercelak; and a profound disconnection between the frenzied festivalized event and the everyday space of the city in the aftermath of New Year's Eve celebrations in Wrocław. All three, however, show festivals as bounded events clearly separated from the quotidian experience of the city.

Festivals are often described in terms of their carnivalesque potential to 'challenge, re-order, subvert and disrupt' (Quinn, 2005: 934), of being a liminal 'time out of time' space (Bakhtin, 1984), or of its ability to deterritorialize and reterritorialize urban space (Deleuze and Guattari, 1986). The oft-repeated hope is thus that the festival enriches and transforms the city it occurs in. However, it can be discussed whether this is indeed the case for many contemporary festivals. In line with controlling the experience production process as stated above, organizers tend to take strong steps to carefully control the construction and management of festival space, as also exemplified by the cases presented in this paper. Such festivals present a sanitized version of the city rather than its life in all its complexity and multiplicity. Instead of displaying ambivalence and multivocality, of breathing new life into the urban space, festivals are a device put in place to promote a coherent, healthy picture of the city planned well in advance of the festival.

As well as presenting a sanitized version of the city's cultural landscape, the festival also serves to hide from view the less palatable elements of the urban experience. In evaluating the role and impact of festivals, detrimental consequences such as crime, noise, and littering, and the potential negative effects on the local inhabitants tend to be neglected. Building on Kociatkiewicz and Kostera (2010) we therefore acknowledge the imperative for further exploration of the shadow, the inevitable darker side of the ostentatious experience economy. For urban planning and policy-making this means paying attention to the potential exclusion that cultural events staged with an eye towards city promotion can produce, for example in terms of neglecting permanent residents in favour of temporary visitors. Care must also be taken to account for all the potential consequences of a cultural and physical gentrification, including negative ones.

At the same time, we believe urban space is necessarily unruly and that vibrant festival space or, rather, festivalization of space is indeed crucial for the continued functioning of the city. Bakhtinian carnival reverses social hierarchy and subverts social roles to relieve communal tensions, strengthening social ties and helping community grow. It helps bring about change as it

tests and contests all aspects of society and culture through festive laughter: those that are questionable may be readied for change; those that are deemed legitimate may be reinforced (LaCapra, 1983/2003: 43).

Similarly, an urban festival creating a liminal space between the orderly ambitions of its organizers, and the passionate and sometimes destructive impulses of its participants can inscribe urban space with novel meanings available for later preservation, defacement, and reinterpretation. It imbues the city with life. Creating experiences, within or without an experience economy, requires the freedom to experiment with the practices and meanings of city space. These meanings, however, although perhaps carefully outlined in terms of what they should preferably bring, are always open to alternative interpretations.

\section{References}

AEA (2006) Thundering Hooves. Maintaining the Global Competitive Edge of Edinburgh's Festivals. Report commissioned by the Scottish Arts Council. Online resource, http:// www.scottisharts.org.uk/1/information/ publications/1003373.aspx. Accessed 15 January, 2010.

Andersson K (2006) Nära en Halv Miljon Såg Festival. Svenska Dagbladet, 21 August. Online resource, http://www.svd.se/kulturnoje/nyheter/ nara-en-halv-miljon-sag-festival_345580.svd. Accessed 12 February, 2010. 
Anholt S (2008) Place Branding: is it Marketing, or isn't it? Place Branding and Public Diplomacy 4/1: 1-6.

Avdikos, V (2011) Local hegemonic blocs: The case of tourism in Rhodes, European Urban and Regional Studies 18 (1): 77-92.

Bakhtin M (1984) Rabelais and His World. Bloomington: Indiana University Press.

Baudrillard J (1985/94) Simulacra and Simulation. Ann Arbor: University of Michigan Press.

Boldemann M (2005) Kulturfest i Stan utan Öltält. Dagens Nyheter, 1 September. Online resource, http://www.dn.se/kultur-noje/kulturfest-i-stanutan-oltalt-1.383159. Accessed 12 February, 2010.

Boldemann M (2006) Årets Kulturfestival Blev en Publiksuccé. Dagens Nyheter, 21 August. Online resource, http://www.dn.se/kultur-noje/aretskulturfestival-blev-en-publiksucce-1.655797. Accessed 12 February, 2010.

Brandel T (2006) Moderater Stödjer Kulturfestival. Svenska Dagbladet, 18 August. Online resource, http://www.svd.se/kulturnoje/nyheter/ moderater-stodjer-kulturfestival_344910.svd. Accessed 12 February, 2010.

Carp O (2005) Festival i Fara trots Storpublik. Svenska Dagbladet, 6 September. Online resource, http://www.svd.se/kulturnoje/nyheter/ festival-i-fara-trots-storpublik_454073.svd. Accessed 12 February, 2010.

Castells M (1996) The Rise of the Network Society. The Information Age: Economy, Society and CultureVolume I. Malden: Blackwell.

Crang M (2001) Rhythms of the City. In: May J and Thrift N (ed.) Timespace. Geographies of Temporality. London: Routledge, 187-207.

de Certeau M (1984) The Practice of Everyday Life. Berkeley: University of California Press.

Czarniawska B (1994) Narratives of Individual and Organizational Identities. In: Deetz S (ed.) Communication Yearbook 17. London: SAGE, 193-221.
Deleuze G and Guattari F (1986) Nomadology: The War Machine. New York: Semiotext(e).

Du Gay P and Pryke M (eds) (2002) Cultural Economy: Cultural Analysis and Commercial Life. London: SAGE.

European Festivals Association (2009) European Festivals: Driving Success Through Culture. Report from seminar held in Brussels 2 December, 2009. Online resource, http://www. efa aef.eu/en/association/news/detail/909/ Seminar\%20pleas\%20for\%20recognition $\% 20$ of $\% 20$ festivals $\% 20$ as $\% 20$ artistic $\% 2 c \% 20$ economic $\% 20$ and $\% 20$ social $\% 20$ driving $\% 20$ force/. Accessed 15 January, 2010.

Gyimóthy S (2005) Nostalgiascapes. Copenhagen: Copenhagen Business School Press.

Haapala A (2005) On the Aesthetics of the Everyday. Familiarity, Strangeness, and the Meaning of Place. In: Light A and Smith JM (eds) The Aesthetics of Everyday Life. New York: Columbia University Press, 39-55.

Harvey D (1990) The Condition of Postmodernity. Oxford: Blackwell.

Hayes D and Macleod N (2007) Packaging Places: Designing Heritage Trails Using an Experience Economy Perspective to Maximize Visitor Engagement. Journal of Vacation Marketing 13/1: 47-58.

Herrero LC, Sanz A, Devesa M, Bedate A, and del Barrio MJ (2007) Economic Impact and Social Performance of Cultural Macrofestivals. In: Richards G (ed) Cultural Tourism. Global and Local Perspectives. Binghamton: The Haworth Hospitality Press, 303-328.

Hjorth D and Kostera M (eds) (2007) Entrepreneurship and the Experience Economy. Copenhagen: Copenhagen Business School Press.

Hobsbawm E (1983) Introduction: Inventing Traditions. In: Hobsbawm E and Ranger T (eds) The Invention of Tradition. Cambridge: Cambridge University Press, 1-14.

Hudson S and Ritchie JRB (2009) Branding a Memorable Destination Experience. The Case of 
'Brand Canada'. International Journal of Tourism Research, 11/2: 217-228.

Huizinga J (1924/2001) Waning of the Middle Ages. London: Penguin.

Ingelman-Sundberg C (2009) Finsk Tema på Kulturfestivalen. Svenska Dagbladet, 12 May. Online resource, http://www.svd. se/kulturnoje/nyheter/finskt-tema-pakulturfestivalen_2876145.svd. Accessed 12 February, 2010.

Jamieson K (2004) The Festival Gaze and its Boundaries. Space \& Culture 7/1: 64-75.

Karpińska-Krakowiak M (2009) Festivalisation of the City. Contemporary Examples. Urban People 11/2: 338-350.

Klingmann A (2007) Brandscapes: Architecture in the Experience Economy. Cambridge, MA: MIT Press.

Kociatkiewicz J and Kostera M (2001) The Pope as Organizing Principle. In: Czarniawska B and Solli R (eds) Organizing Metropolitan Space and Discourse. Malmö: Liber, 154-174.

Kociatkiewicz J and Kostera M (2010) Experiencing the Shadow: Organizational Exclusion and Denial within Experience Economy. Organization, 17/2: 257-282.

Kołodziejska A (2008) Powróćmy na Kercelak. Kurier Wolski 4(305): 1-5.

Kristeva J (1982) Powers of Horror: An Essay on Abjection. New York: Columbia University Press.

LaCapra D (1983/2003) Bakhtin, Marxism, and the Carnivalesque. In: Gardiner ME (ed.) Mikhail Bakbtin, volume II. London: SAGE.

Laquist E (2009) Kulturfest Breddar Sitt Utbud. Dagens Nyheter, 10 August. Online resource, http://www.dn.se/kultur-noje/nyheter/ kulturfest-breddar-sitt-utbud-1.927761. Accessed 12 February, 2010.

Lefebvre H (1992/2004) Rhythmanalysis. Space, Time and Everyday Life. London: Contin.

Lefebvre H (1974/91) The Production of Space. Oxford: Blackwell.
Lévi-Strauss C (1962/6) The Savage Mind. Chicago: University of Chicago Press.

Lorentzen A (2009) Cities in the Experience Economy. European Planning Studies 17/6: 829845.

Lorentzen A and Jahn Hansen C (2009) The Role and Transformation of the City in the Experience Economy: Identifying and Exploring Research Challenges. European Planning Studies 17/6: 817-827.

Löfgren O and Willim R (2005) Introduction: The Mandrake Mode. In: Löfgren $\mathrm{O}$ and Willim R (eds) Magic, Culture and the New Economy. Oxford: Berg, 1-19.

Markusen A and Shrock G (2006) The Distinctive City: Divergent Patterns in Growth, Hierarchy and Specialisation. Urban Studies 43/8: 13011323

Marling G, Jensen OB, and Kiib H (2009) The Experience City: Planning of Hybrid Cultural Projects. European Planning Studies 17/6: 863885.

Morgan M, Elbe J, and de Esteban Curiel J (2009) Has the Experience Economy Arrived? The Views of Destination Managers in Three VisitorDependent Areas. International Journal of Tourism Research 11/2: 201-216.

Murzyn MA (2006) Kazimierz: The Central European Experience of Urban Regeneration. Kraków: International Cultural Centre.

Nilsson Å-M 2005. Kulturfestival ska liva upp city. Svenska Dagbladet, 24 August. Online resource, http://www.svd.se/kulturnoje/nyheter/ kulturfestival-ska-liva-upp-city_450185.svd. Accessed 12 February, 2010.

Nyström M (2007) Kulturfestivalen. Dagens Nyheter, 16 August. Online resource, http://www.dn.se/ kultur-noje/kulturfestivalen-1.623518. Accessed 12 February, 2010.

O'Dell T (2005) Experiencescapes: Blurring Borders and Testing Connections. In: O'Dell T and Billing P (eds) Experiencescapes: Tourism, Culture and Economy. Copenhagen: Copenhagen Business School Press, 11-33. 
Oh H, Fiore AM, and Jeoung M (2007) Measuring Experience Economy Concepts: Tourism Applications. Journal of Travel Research 46/2: 119-132.

Pine JB and Gilmore JH (1999) The Experience Economy. Work Is Theatre and Every Business a Stage. Boston: Harvard Business School Press.

Quinn B (2005) Arts Festivals and the City. Urban Studies 42/5-6: 927-943.

Richards G (2007) The Festivalization of Society or the Socialization of Festivals? The Case of Catalunya. In: Richards G (ed) Cultural Tourism. Global and Local Perspectives.

Binghamton: The Haworth Hospitality Press, 257-280.

Russo AP and Sans AA (2009) Student Communities and Landscapes of Creativity. How Venice

- 'The World's Most Touristed City' - Is Changing. European Urban and Regional Studies 16/2: 161-175.

Schulze G (1992) Die Erlebnisgesellschaft. Kultursoziologie der Gegenwart. Frankfurt/Main: Campus Verlag.

Smith, A. and von Krogh Strand, I (2011) Oslo's new Opera House: Cultural flagship, regeneration tool or destination icon? European Urban and Regional Studies 18 (1):93-110

Sundbo J and Darmer P (2008) Creating Experiences in the Experience Economy. Cheltenham: Edward Elgar.

Toffler A (1970) Future Shock. New York: Random House.

Tuan, YF (1977) Space and Place: The Perspective of Experience. Minneapolis: University of Minnesota Press.

Urry J (2000) Sociology Beyond Societies: Mobilities for the Twenty First Century. London: Routledge.

Waterman S (1998) Carnivals for élites? The cultural politics of arts festivals. Progress in Human Geograpy 22/1: 54-74.

Yeoman I, Robertson M, Ali-Knight J, Drummond S, and McMahon-Beattie U (eds) (2004) Festival and Events Management. An International
Arts and Culture Perspective. Oxford: Elsevier Butterworth-Heinemann.

Young C and Kaczmarek S (2008) The Socialist Past and Postsocialist Urban Identity in Central and Eastern Europe. The Case of Łódź, Poland. European Urban and Regional Studies 15/1: 53 70.

Zukin S (1995) The Cultures of Cities. Cambridge, MA: Blackwell. 